\title{
Contents, Vol. 57, 1990
}

\section{No. 1 Original Paper}

Unconjugated and Conjugated Bilirubin Pigments during Perinatal Development. II. Stud ies on Serum of Healthy Newborns and of Neonates with Erythroblastosis fetalis

Muraca, M.; Rubaltelli, F.F.; Blanckaert, N.; Fevery, J 1

Radiant Heat Loss versus Radiant Heat Gain in Premature Neonates under Radiant

Warmers

Baumgart, S 10

Free Cortisol of Human Plasma in the First Three Months of Life

Rokicki, W.; Forest, M.G.; Loras, B.; Bonnet, H.; Bertrand, J

Effect of Colostrum Feeding on Protein Metabolism in the Small Intestine of Newborn Lambs

Patureau Mirand, P.; Mosoni, L.; Levieux, D.; Attaix, D.; Bayle, G.; Bonnet, Y. . . 30

Lipoprotein Lipase Activity in the Liver of Starved Pregnant Rats

Vilaró, S.; Testar, X.; Ramirez, I.; Llobera, M

Metabolic Effects of the Delay in Obliteration of the Umbilical Cord in the Newborn

Rat

Arranz, L.; Ruiz, M.A.; Fernandez, E.; Medina, J.M 46

Categorization of Near-Term Mouse Fetuses According to Their Viability as a Tool for

Developmental Toxicity Screening

Pinto-Machado, J. 54

Acknowledgement 60

No. 2 Original Paper

Factors That Influence the Distention of Immature Lung with Artificial Surfactant

Ferrer-Roca, O.; Padilla, M.C.; Domenech, E

61

Hemoglobin Oxygen Dissociation (P5o) in Bronchopulmonary Dysplasia

Furfaro, S.; Prosmanne, J.; Bard, H 72

Cardiorespiratory Patterns in Infants Presenting with Apparent Life-Threatening Epi sodes

Southall, D.P.; Janczynski, R.E.; Alexander, J.R.; Taylor, V.G.; Stebbens, V.A 77

IV

Contents

Observations on the Intestinal Colonization by Pseudomonas aeruginosa in Newborn Infants

Borderon, E.; Thieffry, J.C.; Jamet, O.; Poisson, D.; Boisseau, C; Farid, I.A 88

Relationship of Urinary Anion Gap to Urinary Ammonium Excretion in the Neonate

Sulyok, E.; Guignard, J.-P 98

Effect of a Low Protein Diet during Pregnancy on the Fetal Rat Endocrine Pancreas

Snoeck, A.; Remade, C; Reusens, B.; Hoet, JJ 107

Effect of Postnatal Hypoxia on Ammonia Metabolism during the Early Neonatal Period in the Rat 
Vicario, C; Juanes, M.C.; Martín-Barrientos, J.; Medina, J.M

Vitamin A Storage in Lungs during Perinatal Development in the Rat

Shenai, J.; Chytil, F 126

Maternal Caffeine Ingestion Increases the Tyrosine Level in Neonatal Rat Cerebrum

Tanaka, H.; Nakazawa, K 133

Announcement $\quad 140$

No. 3-4 Original Paper

Hepatic Impairment in Fetuses of Preeclamptic Mothers

Lox, C; Harral, A.; Corrigan, J.J 141

Sleep Apneas and Acid Esophageal Reflux in Control Infants and in Infants with an Apparent Life-Threatening Event

Kahn, A.; Rebuffat, E.; Sottiaux, M.; Blum, D.; Yasik, E.A 144

Correlation between Levels of Plasma Adenosine Triphosphate and Stress to the Fetus at

Delivery

Fukuda, S.; Katoh, S.; Yamamoto, K.; Hashimoto, M.; Kitao, M 150

Metabolism of Intravenous Phenylalanine by Babies Born before 33 Weeks of Gestation

Walker, V.; Mills, G.A 155

Correlation of Commonly Used Measures of Intrauterine Growth with Estimated Neonatal

Body Fat

Wolfe, H.M.; Brans, Y.W.; Gross, T.L.; Bhatia, R.K.; Sokol, R.J 167

Cis- and rrans-Isomeric Fatty Acids in Plasma Lipids of Newborn Infants and Their Mothers

Koletzko, B.; Müller, J 172

Differences in Sialic Acid Expression of Lung Alveolar Cells between Normal and Intrauterine Growth-Retarded Rat Fetuses

Konishi, H.; Ghazizadeh, M.; Araki, T 179

Postnatal Development of Enzyme Activities Associated with Protection against Oxidative

Stress in the Mouse

Harman, A.W.; McKenna, M.; Adamson, G.M 187

Neutral and Acidic Goblet Cell Concentrations in the Small Intestine of the Unweaned Pig

Dunsford, B.R.; Haensly, W.E.; Knabe, D.A 194

Intrauterine Exposure to Parathion Increases Its Disposition Rate in Postnatal Life

Jaramillo, F.; Reyes, J.L 200

Congenital Malformations in Offspring of Diabetic Rats: Experimental Study on the

Influence of the Diet Composition and Magnesium Intake

Giavini, E.; Prati, M.; Roversi, G 207

Influence of an Alpha-1-Adrenoceptor Antagonist, Nicergoline, on Placental Prostanoid

Production in Streptozotocin-Induced Diabetic Pregnant Rats

Chartrel, N.; Clabaut, M.; Boismare, F.; Schrub, J.C 218

Contents V

Effect of Hyperthermia on Thyroid Structure in the Late Gestation Fetal Lamb

Andrianakis, P.; Stephenson, R.G.A.; Walker, D.W 224

Effect on the Fetus of Infusing a Commercial Amino Acid Preparation into a Pregnant

Sheep

MacMahon, R.A.; Frampton, R.J.; Yardley, R.W 231

Carbon Monoxide Production by Nonbacterial Sources after Heme Feeding of Neonatal

Rats 
Stevenson, D.K.; Hamori, C.J.; Cariton, R.R.; Castillo, R.O.; Kerner, J.A., Jr.; Vreman, H.J. 238

Morphometrical Studies on Perinatal Development of Glomerular Components in Rat

Okada, T.; Morikawa, Y 243

Furosemide Increases Total Calcium in Kidney and Cytoplasmic Free Calcium in Blood

Mononuclear Cells of Guinea Pigs

Tsao, P.W.; Klip, A.; Radde, I.C 250

Brief Communication

1,25(OH)2D3 Stimulates Phospholipid Biosynthesis and Surfactant Release in Fetal Rat

Lung Explants

Marin, L.; Dufour, M.E.; Tordet, C; Nguyen, M 257

No. 5 Editorial

Brain Damage in Monozygous Twins

Larroche, J.O.; Droullé, P.; Delezoide, A.L.; Narcy, F.; Nessmann, C 261

Original Paper

Group-Specific Component in Neonatal Breast Secretion: Relationship to the Cellular

Content

Pittard, W.B., III; Geddes, K.M.; Katikaneni, L.P.; Sillivant, R.E.; Galbraith, R.M. . 279 Total

Body Water Measurement in Normal and Diabetic Pregnancy: Evidence for Maternal

and Amniotic Fluid Equilibrium

Denne, S.C.; Patel, D.; Kalhan, S.C 284

Inorganic Sulfate Metabolism in the Very Low Birthweight Infant

Cole, D.E.C.; Evans, J.R.; Raad, M.; Hamilton, D.C 292

Altered Maternal Thyroid Function: Fetal and Neonatal Myocardial Metabolism

Kumar, R.; Cbaudhuri, B.N 300

Effects of Changes in Oxygen Tension on Lipoxygenase Metabolites. Serum 15-HETE Is Increased in Kittens Exposed to Hyperoxia

Stuart, M.J.; Walenga, R.W.; Setty, B.N.Y.; Phelps, D.L 313

Epidermal Growth Factor Administered in Pregnancy Has Little Effect on Placental, Fetal and Postnatal Growth and Development in Rats

Ali, P.; D’Souza, S.W.; Smart, J.L 318

No. 6 Original Paper

Effect of Fibrinogen Degradation Products and Lung Ground Substance on Surfactant

Function

O’Brodovich, H.M.; Weitz, J.L; Possmayer, F 325

Reduced Platelet Counts in Neonatal Respiratory Distress Syndrome

Kohelet, D.; Perlman, M.; Hanna, G.; Ballin, A 334

VI Contents

Cyclic Guanosine Monophosphate Metabolism in Human Amnion Cells Trisomic for

Chromosome 21

Karlsson, J.O.G.; Sjöstedt, A.; Wahlström, J.; Axelsson, K.L.; Andersson, R.G.G. . 343

Development of Peroxisomal B-Oxidation Activities in Brown Fat of Perinatal Rabbits

Mangurian, L.P.; Donaldson, R.P 349

Ontogenic Characterization of Type I and II Thyroxine 5'-Monodeiodinases in Brown

Adipose Tissue from Fetal and Newborn Rabbits

Brzezińska-Sİebodzińska, E.; Kapluk, J 358

Dose-Related and Other Effects of Maternal Cimetidine Pretreatment during Lactation on 
Drug Metabolism in Mouse Dams and Pups

Osuide, G.; Wambebe, C; Ikediobi, CO.; Kwanashie, H.0 367

Author Index 375

Subject Index 377 